\title{
Malarial pancreatitis: Case report and systematic review of the literature
}

\author{
Inderpaul Singh Sehgal, Ritesh Agarwal, Digambar Behera, Sahajal Dhooria
}

Malaria can cause a wide spectrum of clinical manifestations ranging from uncomplicated
febrile illness to multiorgan failure. Pancreatitis is a rare complication of malaria with only a
few reported cases. Herein, we describe a case of acute pancreatitis with multiorgan failure
due to Plasmodium falciparum managed successfully with antimalarials and conservative
treatment. We also perform a systematic review of literature for reports of acute
pancreatitis due to Plasmodium infection.
Keywords: Abdominal pain, acute respiratory distress syndrome, malaria, multiorgan
dysfunction, pancreatitis

\section{Introduction}

Malaria is one of the most important protozoan parasitic infection of humans and remains endemic in India. It is responsible for $1.8 \%$ of cumulative deaths before the age of 70 years. $^{[1]}$ It is one of the common causes of acute febrile illness in endemic areas and can cause single or multiorgan dysfunction including acute renal failure, acute respiratory distress syndrome (ARDS), jaundice, myocarditis, hemolytic anemia, coma, and others. ${ }^{[2,3]}$ Acute pancreatitis is a rare manifestation of malaria with only a few cases reported in literature. Herein, we report a case of acute pancreatitis and multiorgan dysfunction caused by Plasmodium falciparum. We also perform a systematic review of literature on acute pancreatitis caused by malaria.

\section{Case Report}

A 40-year-old man presented with acute onset high-grade fever, jaundice, and abdominal pain of 10 days duration. He did not have any vomiting, passage

From:

Department of Pulmonary Medicine, Postgraduate Institute of Medical Education and Research, Chandigarh, India

\section{Correspondence:}

Dr. Sahajal Dhooria, Department of Pulmonary Medicine, Postgraduate Institute of Medical Education and Research, Chandigarh - 160 012, India.

E-mail: sahajal@gmail.com

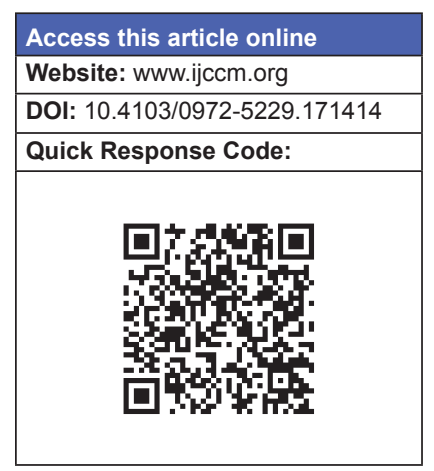

of clay-colored stools, or any alteration in his bowel habit. Three days before the presentation, the patient had also developed breathlessness, drowsiness, and decreased urine output. There was no cough, chest pain, or hemoptysis. There was no history of any seizures, sensory or motor complaints. The patient did not have any comorbidities or addictions. On examination, the pulse rate was 124 per min, respiratory rate 40 per min, blood pressure $100 / 60 \mathrm{mmHg}$, and temperature $101^{\circ} \mathrm{F}$. Glasgow coma score was 10. Pallor and icterus were present. Auscultation of the chest revealed bilateral basal crackles. The abdomen was distended with epigastric tenderness and hepatosplenomegaly.

Investigations revealed anemia, thrombocytopenia, and neutrophilic leukocytosis with deranged renal and liver functions [Table1]. Peripheral blood examination showed

This is an open access article distributed under the terms of the Creative Commons Attribution-NonCommercial-ShareAlike 3.0 License, which allows others to remix, tweak, and build upon the work non-commercially, as long as the author is credited and the new creations are licensed under the identical terms.

For reprints contact: reprints@ medknow.com

How to cite this article: Sehgal IS, Agarwal R, Behera D, Dhooria S. Malarial pancreatitis: Case report and systematic review of the literature. Indian J Crit Care Med 2015;19:743-6. 
trophozoites of P. falciparum (parasite index 1.5\%) and rapid diagnostic test (QDx Malaria Pv/Pf malaria card test, Piramal Healthcare Limited, India) for P. falciparum was positive. Hypoxemia $\left(\mathrm{PaO}_{2} / \mathrm{FiO}_{2}\right.$ ratio $\left.=69\right)$ was present with bilateral alveolar opacities on chest radiograph suggesting ARDS [Figure 1]. Bacterial cultures of blood and endotracheal aspirate were sterile throughout the hospital stay. Serum amylase was $391 \mathrm{U} / \mathrm{L}$ and lipase was $753 \mathrm{U} / \mathrm{L}$ [Table 1]. Contrast enhanced computed tomography (CT) scan of the abdomen revealed evidence of pancreatitis with a modified CT score of 10 [Figure 2] and bedside index of

\begin{tabular}{|c|c|c|}
\hline Parameter & Baseline & At discharge \\
\hline Hemoglobin (g/dL) & 8.0 & 12.8 \\
\hline Total leukocyte count (cells/mm³) & 12,100 & 8000 \\
\hline Platelet count $\left(\times 10^{3} / \mathrm{mm}^{3}\right)$ & 17 & 330 \\
\hline Blood urea $(\mathrm{mg} / \mathrm{dL})$ & 290 & 54 \\
\hline Serum creatinine $(\mathrm{mg} / \mathrm{dL})$ & 8.6 & I.I \\
\hline Serum albumin $(\mathrm{g} / \mathrm{dL})$ & 2.2 & 3.5 \\
\hline Serum bilirubin (mg/dL) & 30.0 & 2.3 \\
\hline Alanine transaminase $(\mathrm{U} / \mathrm{L})$ & 23 & 22 \\
\hline Aspartate transaminase $(\mathrm{U} / \mathrm{L})$ & 72 & 45 \\
\hline Alkaline phosphatase $(\mathrm{U} / \mathrm{L})$ & 71 & 60 \\
\hline Serum calcium (mg/dL) & 9.0 & 8.9 \\
\hline Serum LDH (U/L) & 250 & 167 \\
\hline Serum triglycerides $(\mathrm{mg} / \mathrm{dL})$ & 398 & 180 \\
\hline Serum amylase (U/L) & 391 & 63 \\
\hline Serum lipase (U/L) & 753 & 15 \\
\hline Serum procalcitonin $(\mu \mathrm{g} / \mathrm{L})$ & 54.5 & 0.2 \\
\hline $\mathrm{PaO}_{2} / \mathrm{FiO}_{2}$ ratio & 68.8 & 300.0 \\
\hline $\mathrm{HCO}_{3}{ }^{-} \mathrm{mmol} / \mathrm{L}$ & 14.0 & 25.0 \\
\hline Blood culture & Sterile & Sterile \\
\hline Tracheal aspirate culture & Sterile & Sterile \\
\hline Intraabdominal pressure (cm of saline) & 28.0 & 8.0 \\
\hline IgM (ELISA) Leptospira & Negative & \\
\hline IgM (ELISA) for dengue virus & Negative & \\
\hline PCR for 0. tsutsugamushi & Negative & \\
\hline
\end{tabular}

ELISA: Enzyme-linked immunosorbent assay; $\mathrm{FiO}_{2}$ : Fractional inspired oxygen; $\mathrm{LDH}$ : Lactate dehydrogenase; $\mathrm{PaO}_{2}$ : Arterial partial pressure of oxygen; $\mathrm{PCR}$ : Polymerase chain reaction; $\mathrm{S}$ : Serum; U: Units; O. tsutsugamushi: Orientia tsutsugamushi

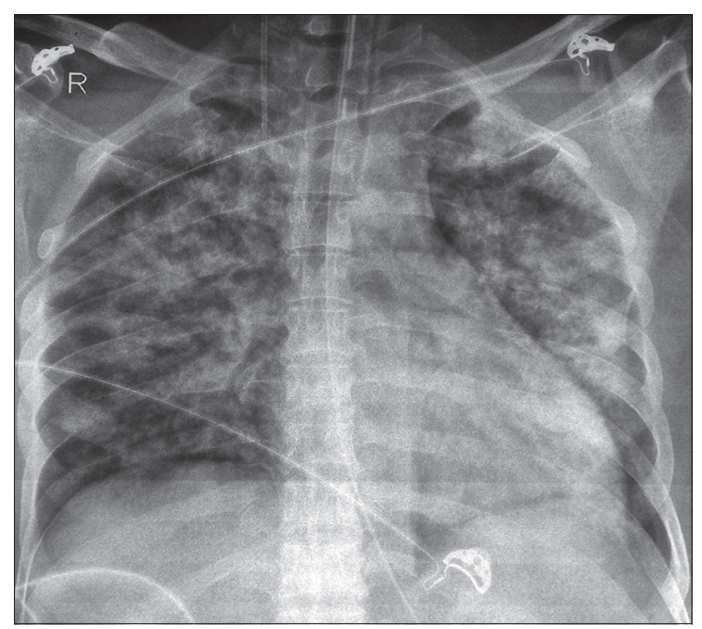

Figure I: Chest radiograph showing bilateral infiltrates consistent with acute respiratory distress syndrome severity in acute pancreatitis (BISAP) score of 4 . There were no gallstones on ultrasound or $\mathrm{CT}$ of the abdomen.

The patient was diagnosed as severe falciparum malaria with acute pancreatitis. He was electively intubated and mechanically ventilated. He was kept nil per oral and a nasogastric tube was placed. Intravenous artesunate $(120 \mathrm{mg}$ every $12 \mathrm{~h}$ for 3 days followed by $120 \mathrm{mg}$ every $24 \mathrm{~h}$ ) and oral doxycycline ( $200 \mathrm{mg} /$ day in two divided doses) were administered. Despite treatment, there was progressive abdominal distension with the development of abdominal compartment syndrome (indicated by a high abdominal pressure of $28 \mathrm{~cm}$ of saline, hypotension, and worsening renal failure). Intravenous normal saline, vasopressors (noradrenaline and vasopressin), and intravenous meropenem were started. An abdominal drain was placed to decrease the intraabdominal pressure, and intermittent hemodialysis was performed.

Abdominal pressure decreased, fever abated, and hypotension resolved on the $5^{\text {th }}$ day. Renal function improved and dialysis was stopped after six sessions. The patient was subsequently discharged after 4 weeks of hospitalization and continued to do well on follow-up.

\section{Discussion}

The case highlights that acute pancreatitis can occasionally complicate the course of falciparum malaria. We made a diagnosis of malaria-associated pancreatitis as the patient did not consume alcohol; there were no gallstones on abdominal imaging, no history of consumption of any drug known to cause pancreatitis and normal serum calcium with only mildly raised serum triglycerides. Although the exact mechanism of pancreatitis is unclear,

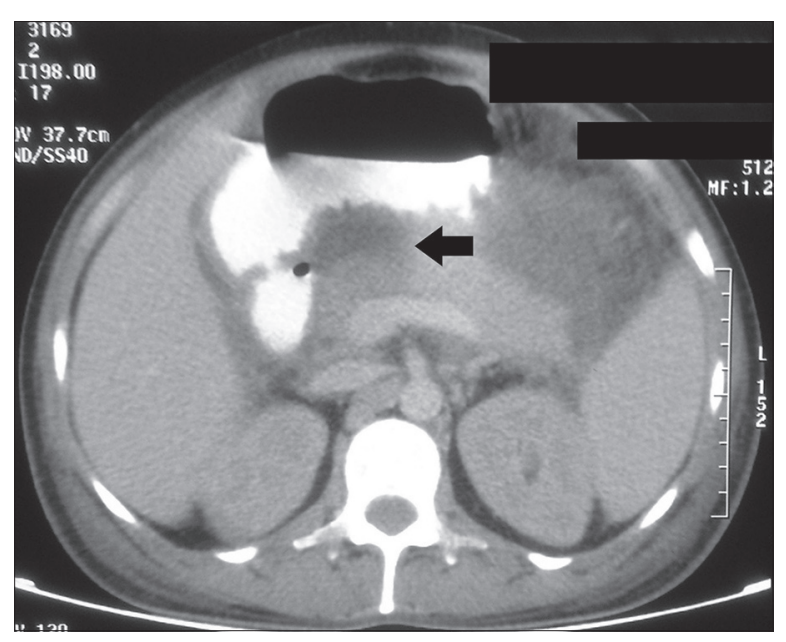

Figure 2: Contrast enhanced computed tomography of the abdomen showing pancreatic necrosis 
the possible reason can be obstruction of capillaries due to parasite-laden erythrocytes causing ischemic damage to pancreatic parenchyma or massive hemolysis associated with malaria. ${ }^{[4-6]}$

Pancreatitis as a complication of malaria is a rare entity with the first case reported in $1907 .{ }^{[7]}$ A systematic review of the PubMed and EmBase databases using the search string ("malaria" or "falciparum" or "vivax" or "malariae" or "ovale") and "pancreatitis" yielded 18 reports (22 cases) on pancreatitis caused by malaria [Table 2]. $\cdot^{[4,-24]}$ The most common species responsible was $P$. falciparum $(17 / 22)$, which was also the causative species in the index case. Abdominal pain was reported in all cases while icterus was seen in 12 cases. Abdominal pain in malaria can be due to

Table 2: Studies reporting pancreatitis due to malaria

\begin{tabular}{|c|c|c|c|c|c|c|c|c|c|c|c|c|c|}
\hline $\begin{array}{l}\text { Author } \\
\text { (year) }\end{array}$ & $\begin{array}{l}\text { Number } \\
\text { of patients }\end{array}$ & $\begin{array}{c}\text { Age } \\
\text { (years) }\end{array}$ & Gender & $\begin{array}{l}\text { Abdominal } \\
\text { pain }\end{array}$ & & $\begin{array}{l}\text { Serum } \\
\text { amylase } \\
\text { (U/L) }\end{array}$ & $\begin{array}{l}\text { Serum } \\
\text { lipase } \\
\text { (U/L) }\end{array}$ & Severity & Species & $\begin{array}{c}\text { Parasite } \\
\text { index } \\
(\%)\end{array}$ & $\begin{array}{l}\text { Organ } \\
\text { failure }\end{array}$ & $\begin{array}{l}\text { Treatment } \\
\text { given }\end{array}$ & $\begin{array}{l}\text { Final } \\
\text { outcome }\end{array}$ \\
\hline $\begin{array}{l}\text { Johnson } \\
\text { et al. }(1977)^{[20]}\end{array}$ & I & 26 & Male & Yes & Yes & NA & NA & NA & P. falciparum & NA & $\begin{array}{l}\text { Pleural } \\
\text { effusion }\end{array}$ & Antimalarial & $\overline{\text { Survived }}$ \\
\hline $\begin{array}{l}\text { Gurman } \\
\text { et al. }(1988)^{[8]}\end{array}$ & I & 19 & Female & Yes & Yes & NA & NA & NA & P. falciparum & 2 & ARDS & $\begin{array}{l}\text { Quinine and } \\
\text { tetracycline }\end{array}$ & Survived \\
\hline $\begin{array}{l}\text { Druml } \\
\text { et al. }(1991)^{[4]}\end{array}$ & I & 25 & Female & Yes & NA & 651 & NA & NA & NA & NA & $\begin{array}{l}\text { Renal failure, } \\
\text { altered } \\
\text { sensorium, } \\
\text { DIC }\end{array}$ & Antimalarial & Survived \\
\hline $\begin{array}{l}\text { Sarma and } \\
\text { Kumar (1998) }\end{array}$ & I & 17 & Male & Yes & Yes & 2132 & NA & Severe & P. falciparum & 1.5 & No & Quinine & Survived \\
\hline $\begin{array}{l}\text { Praetorius } \\
\text { et al. }(1999)^{[10]}\end{array}$ & I & 67 & Female & Yes & No & NA & NA & Severe & P. falciparum & 10 & $\begin{array}{l}\text { Renal } \\
\text { failure, } \\
\text { ARDS }\end{array}$ & $\begin{array}{l}\text { Mefloquine, } \\
\text { quinine }\end{array}$ & Survived \\
\hline $\begin{array}{l}\text { Desai } \\
\text { et al. }(200 \mathrm{I})^{[11]}\end{array}$ & 2 & 40,58 & $\begin{array}{l}\text { Male (I), } \\
\text { female (I) }\end{array}$ & Yes $(2 / 2)$ & Yes $(2 / 2)$ & $\begin{array}{l}535 \\
133\end{array}$ & $\begin{array}{l}1329 \\
1037\end{array}$ & Moderate & $\begin{array}{l}\text { P. falciparum } \\
(2 / 2)\end{array}$ & 0.5 & Renal failure & $\begin{array}{l}\text { Artemether, } \\
\text { mefloquine, } \\
\text { artesunate, } \\
\text { doxycycline }\end{array}$ & Survived \\
\hline $\begin{array}{l}\text { Seshadri } \\
\text { et al. }(2008)^{[12]}\end{array}$ & 1 & 21 & Male & Yes & Yes & 1712 & 5217 & Severe & $\begin{array}{l}\text { P. falciparum } \\
\text { and } P \text { vivax }\end{array}$ & 45 & $\begin{array}{l}\text { Renal failure, } \\
\text { subdural } \\
\text { hematoma }\end{array}$ & $\begin{array}{l}\text { Artesunate, } \\
\text { doxycycline, } \\
\text { quinine, } \\
\text { cefepime }\end{array}$ & Survived \\
\hline $\begin{array}{l}\text { Badhal } \\
\text { et al. }(2009)^{[24]}\end{array}$ & I & 33 & Male & Yes & No & NA & NA & Severe & P. falciparum & 1.9 & $\begin{array}{l}\text { Renal } \\
\text { failure, DIC, } \\
\text { hypotension, } \\
\text { altered } \\
\text { sensorium }\end{array}$ & $\begin{array}{l}\text { Artesunate, } \\
\text { quinine, } \\
\text { doxycycline }\end{array}$ & Died \\
\hline $\begin{array}{l}\text { Kumar } \\
\text { et al. }(2010)^{[13]}\end{array}$ & I & 35 & Male & Yes & Yes & 472 & 2460 & Moderate & P. falciparum & 60 & No & $\begin{array}{l}\text { Quinine, } \\
\text { ceftriaxone }\end{array}$ & Survived \\
\hline $\begin{array}{l}\text { Thapa } \\
\text { et al. }(20 \mid 0)^{[14]}\end{array}$ & I & 13 & Male & Yes & Yes & $\mathrm{I}, 456$ & 4562 & Moderate & P. falciparum & 4.5 & Renal failure & $\begin{array}{l}\text { Artesunate, } \\
\text { mefloquine }\end{array}$ & \\
\hline $\begin{array}{l}\text { Mandal } \\
\text { et al. }(20 \mathrm{I} I)^{[15]}\end{array}$ & I & 35 & Male & Yes & Yes & 783 & 2,225 & Severe & P. falciparum & 40 & Renal failure & $\begin{array}{l}\text { Artesunate, } \\
\text { antibiotics }\end{array}$ & Died \\
\hline $\begin{array}{l}\text { Mohapatra and } \\
\text { Gupta }(201 \text { I })^{[16]}\end{array}$ & 3 & $\begin{array}{c}45,28, \\
38\end{array}$ & $\begin{array}{l}\text { Male (2), } \\
\text { female (I) }\end{array}$ & Yes (3/3) & Yes (I/3) & $\begin{array}{c}1200.5 \\
2200.5 \\
2050\end{array}$ & $\begin{array}{l}608.6 \\
860.6 \\
960.8\end{array}$ & $\begin{array}{l}\text { Moderate } \\
\text { to severe }\end{array}$ & $\begin{array}{l}\text { P. falciparum } \\
(3 / 3)\end{array}$ & $6.2-9.2$ & $\begin{array}{l}\text { Renal failure } \\
(1 / 3) \text {, altered } \\
\text { sensorium } \\
(3 / 3)\end{array}$ & $\begin{array}{l}\text { Artesunate, } \\
\text { antibiotics }\end{array}$ & $\begin{array}{l}\text { Survived } \\
(3 / 3)\end{array}$ \\
\hline $\begin{array}{l}\text { Sharma } \\
\text { et al. }(20 \mid 2)^{[17]}\end{array}$ & I & 17 & Male & Yes & Yes & 1234 & NA & Severe & P. vivax & NA & $\begin{array}{l}\text { Renal failure, } \\
\text { hypotension }\end{array}$ & Antibiotics & Died \\
\hline $\begin{array}{l}\text { Atam } \\
\text { et al. }(20 \mid 3)^{[18]}\end{array}$ & I & 42 & Female & Yes & No & 1230 & 800 & Severe & P. vivax & NA & $\begin{array}{l}\text { ARDS, } \\
\text { hypotension }\end{array}$ & $\begin{array}{l}\text { Artesunate, } \\
\text { imipenem }\end{array}$ & Died \\
\hline $\begin{array}{l}\text { Sharma and } \\
\text { Kant }(2013)^{[21]}\end{array}$ & 2 & 62,17 & $\begin{array}{l}\text { Female (I), } \\
\text { male (I) }\end{array}$ & Yes $(2 / 2)$ & No & $\begin{array}{l}11,000 \\
9000\end{array}$ & $\begin{array}{l}\text { NA } \\
400\end{array}$ & Moderate & $\begin{array}{l}\text { P. falciparum } \\
(2 / 2)\end{array}$ & NA & No & Quinine & $\begin{array}{l}\text { Survived } \\
(2 / 2)\end{array}$ \\
\hline $\begin{array}{l}\text { Sundriyal } \\
\text { et al. }(2013)^{[22]}\end{array}$ & I & 35 & Male & Yes & No & 756 & 414 & Moderate & P. vivax & NA & No & $\begin{array}{l}\text { Artesunate, } \\
\text { clindamycin }\end{array}$ & Survived \\
\hline $\begin{array}{l}\text { Ghosh } \\
\text { et al. }(20 \mid 4)^{[19]}\end{array}$ & I & 40 & Male & Yes & Yes & 525 & 250 & Moderate & P. falciparum & NA & No & Artesunate & Survived \\
\hline $\begin{array}{l}\text { Singh } \\
\text { et al. }(20 \mid 4)^{[23]}\end{array}$ & I & 24 & Male & Yes & No & 2800 & 1200 & Moderate & P. falciparum & 60 & No & Artesunate & Survived \\
\hline Index case & I & 40 & Male & Yes & Yes & 398.8 & 391.7 & Severe & P. falciparum & 1.5 & $\begin{array}{l}\text { ARDS, renal } \\
\text { failure, } \\
\text { hypotension }\end{array}$ & $\begin{array}{l}\text { Artesunate } \\
\text { and } \\
\text { doxycycline, } \\
\text { imipenem }\end{array}$ & Survived \\
\hline
\end{tabular}

ARDS: Acute respiratory distress syndrome; DIC: Disseminated intravascular coagulation; NA: Not available; P. falciparum: Plasmodium falciparum; P. vivax: Plasmodium vivax 
various causes such as acalculous cholecystitis, splenic infarction, splenic rupture, hepatitis, acute renal failure, and others. The review suggests that in patients with malaria presenting with abdominal pain, pancreatitis may also be considered as a possible etiology.

The diagnosis of malaria-associated pancreatitis is based upon clinical symptoms (abdominal pain, jaundice, abdominal tenderness, and guarding), laboratory investigations (elevated serum amylase and lipase are seen in 19/22 and 15/22 patients, respectively, in the systematic review), and radiology (ultrasound and contrast-enhanced CT abdomen) and is considered after the common causes of pancreatitis are excluded.

Pancreatitis in malaria might be associated with dysfunction of other vital organs such as renal failure $(n=9)$, ARDS $(n=3)$, hypotension $(n=2)$, which may be attributable to malaria per se or to the ensuing pancreatitis. The index case also had multiorgan dysfunction syndrome (hypotension, ARDS, renal failure, thrombocytopenia, and liver failure). Further, our patient also developed abdominal compartment syndrome (seen in $11 \%$ of cases of pancreatitis of any cause). ${ }^{[25]}$

The index case suffered from severe pancreatitis (BISAP score of 4 ) with a predicted mortality of $>15 \%$. ${ }^{[26]}$ Yet, he responded well to management with intravenous artesunate and doxycycline consistent with the results of the systematic review in which most reported cases had moderate to severe pancreatitis and responded favorably to antimalarial therapy [Table 2]. Four out of 22 (18.2\%) patients died. Of the four patients, one patient did not receive antimalarial therapy (identified postmortem) while in one case, antimalarial therapy was started in the $2^{\text {nd }}$ week of illness. This highlights the importance of the early institution of antimalarial therapy which along with nonsurgical management is usually associated with a favorable outcome.

\section{Conclusion}

Malaria may rarely be complicated by pancreatitis. It is essential to suspect it clinically in patients with abdominal pain, to confirm it early, and to treat it appropriately to have a good outcome.

\section{Financial support and sponsorship Nil.}

\section{Conflicts of interest}

There are no conflicts of interest.

\section{References}

1. Dhingra N, Jha P, Sharma VP, Cohen AA, Jotkar RM, Rodriguez PS, et al. Adult and child malaria mortality in India: A nationally representative mortality survey. Lancet 2010;376:1768-74.

2. White NJ, Pukrittayakamee S, Hien T'T, Faiz MA, Mokuolu OA, Dondorp AM. Malaria. Lancet 2014;383:723-35.

3. Srinivas R, Agarwal R, Gupta D. Severe sepsis due to severe falciparum malaria and leptospirosis co-infection treated with activated protein C. Malar J 2007;6:42.

4. Druml W, Laggner AN, Lenz K, Grimm G, Schneeweiss B. Pancreatitis in acute hemolysis. Ann Hematol 1991;63:39-41.

5. Saruc M, Yuceyar H, Turkel N, Ozutemiz O, Tuzcuoglu I, Yuce G, et al. An experimental model of hemolysis-induced acute pancreatitis. Braz J Med Biol Res 2003;36:879-86.

6. Sonani R, Bhatnagar N, Maitrey G. Autoimmune hemolytic anemia in a patient with Malaria. Asian J Transfus Sci 2013;7:151-2.

7. Egdagl A. A review of 105 reported cases of acute pancreatitis, with special reference to aetiology: With report of two cases. Johns Hopkins Med J 1907;18:130-2.

8. Gurman G, Schlaeffer F, Alkan M, Heilig I. Adult respiratory distress syndrome and pancreatitis as complications of falciparum malaria. Crit Care Med 1988;16:205-6.

9. Sarma PS, Kumar RS. Abdominal pain in a patient with falciparum malaria. Postgrad Med J 1998;74:425-7.

10. Praetorius F, Altrock G, Blees N, Schuh N, Faulde M. Imported anopheles: In the luggage or from the airplane? A case of severe autochthonous malaria tropica near an airport. Dtsch Med Wochenschr 1999;124:998-1002.

11. Desai DC, Gupta T, Sirsat RA, Shete M. Malarial pancreatitis: Report of two cases and review of the literature. Am J Gastroenterol 2001;96:930-2.

12. Seshadri P, Dev AV, Viggeswarpu S, Sathyendra S, Peter JV. Acute pancreatitis and subdural haematoma in a patient with severe falciparum malaria: Case report and review of literature. Malar J 2008;7:97.

13. Kumar S, Jain AP, Vikas. Falciparum malaria presenting as acute pancreatitis. J Vector Borne Dis 2010;47:121-2.

14. Thapa R, Mallick D, Biswas B. Childhood Plasmodium falciparum malaria complicated by acute pancreatitis. Trop Doct 2010;40:184-5.

15. Mandal B, Das BK, Chatterjee SK, Guh P, Shai S, Sharma A, et al. Acute pancreatitis in a case of falciparum malaria - A rare presentation. J Assoc Physicians India 2011;59:731-3.

16. Mohapatra MK, Gupta MP. Falciparum malaria complicated with acute pancreatitis: A report of case series. J Vector Borne Dis 2011;48:177-9.

17. Sharma V, Sharma A, Aggarwal A, Bhardwaj G, Aggarwal S. Acute pancreatitis in a patient with vivax malaria. JOP 2012;13:215-6.

18. Atam V, Singh AS, Yathish BE, Das L. Acute pancreatitis and acute respiratory distress syndrome complicating Plasmodium vivax malaria. J Vector Borne Dis 2013;50:151-4.

19. Ghosh S, Das SK, Sharma A. Unusual presentation of acute pancreatitis in falciparum malaria. Trop Parasitol 2014;4:56-7.

20. Johnson RC, DeFord JW, Carlton PK. Pancreatitis complicating falciparum malaria. Postgrad Med 1977;61:181-3.

21. Sharma S, Kant K. Acute pancreatitis - An unusual complication of falciparum malaria. Indian J Med Case Rep 2013;2:26-8.

22. Sundriyal D, Kumar N, Chandrasekharan A, Sharma B, Patnaik I, Kamble U. Fatal complications of Plasmodium vivax malaria: A series of three case reports. Ann Trop Med Public Health 2013;6:578-80.

23. Singh J, Dinkar A, Atam V, Atam I, Jitender S. An uncommon presentation of severe falciparum Malaria: Acute pancreatitis. Int J Med Sci 2014;2:26-8.

24. Badhal SS, Irshad M, Badhal S, Yadav K. Acute on chronic pancreatitis masking falciparum malaria: A case report. Glob J Health Sci 2009;1:123-5.

25. Gecelter G, Fahoum B, Gardezi S, Schein M. Abdominal compartment syndrome in severe acute pancreatitis: An indication for a decompressing laparotomy? Dig Surg 2002;19:402-4.

26. Singh VK, Wu BU, Bollen TL, Repas K, Maurer R, Johannes RS, et al. A prospective evaluation of the bedside index for severity in acute pancreatitis score in assessing mortality and intermediate markers of severity in acute pancreatitis. Am J Gastroenterol 2009;104:966-71. 